\title{
Employment Patterns of Small and Medium-sized Enterprises - Primary Research in Nitra Region
}

\author{
Enikő KORCSMÁROS
}

J. Selye University, Komárno, Slovakia

korcsmarosedujs.sk

\begin{abstract}
The rapidly changing market conditions of the 21 st century also need to be adapted by companies, which include, among other things, the consideration and study of forms of employment, and possibly the introduction of new forms of employment, as we only think about how fast it is spreading. These forms of employment can be characterized by a distinct mark in terms of typical 8-hour employment, which is typical of the past, and can be mentioned as atypical. The basic aim of the research is to map the employment forms realized by small and medium-sized enterprises in Nitra Region, especially the so-called atypical forms of employment. For the primary data collection we used an online questionnaire survey, we analyzed 320 completed questionnaires. To analyse our research data we used basic descriptive statistical methods, cross-tabulation analysis and distribution. Based on the analysis we have come up with conclusions and suggestions.
\end{abstract}

Keywords: Employment Forms, Atypical Employment, Small and Medium Enterprises.

\section{Introduction}

The economic role of small and medium-sized enterprises is remarkable since they provide a significant ratio of the GDP beside export and import activity. Based on the data of the Slovak Business Agency, more than $70 \%$ of the employees are employed by a company representing the small and medium-sized business sector [14].

The rapidly changing market conditions of the $21^{\text {st. }}$ century forced the companies to consider and study the current employment trends and introduce new forms of employment e.g. home office, part-time job. These forms of employment show completely different characteristics from traditional nine-to-five jobs, and can be called atypical

\section{Theoretical framework}

The issue of different forms of employment has been studied by several domestic and foreign researchers. Kazuya (2005) emphasises, that it is not so easy to clearly define what do we mean under typical and atypical patterns of employment, since what we 
accept today typical was considered to be atypical a few decades ago. Technological and infrastructural developments over the last decades required appropriate solutions, which can be characterized by flexibility [11, 12,]. Hanzelová [5] emphasizes the fact, that the scientific literature does not provide clear definition for typical and atypical patterns of employment. Following the labour market changes of the past period we can assume, that employment with a contract of indefinite duration and not a nine-to-five job can be considered atypical. [9]

The atypical employment patterns provide new possibilities for small and mediumsized enterprises; introduce the possibility to decrease the social contribution costs. Unlike to socially-protected employment status, these new patterns of employment provide numerous advantages and solutions of managing human resources. These new types of employment can cut costs and increases competitiveness and efficiency. [13] Hárs [6] listed the types of atypical employment patterns as the following:

- part-time employees;

- temporary workers (employees with fixed term contract, seasonal workers, casual workers);

- renting workforce;

- work at home, teleworking;

- flexible working hours;

- self-employment.

The increase of atypical employment patterns is driven by changing customer needs and efforts to provide cheaper and more flexible forms of employment. The adaptation to different life cycles and better work-life balance also encourage the increase of atypical patterns of employment. [8]

Part-time employment is one of the most known forms of atypical employment patterns. In case of part-time jobs the working time is reduced to 4-6 hours a day. According to Frey [4], the popularity of part-time employment pattern lies in faster increase of employment rate compared to full time employment pattern. The target group of part-timers can be diverse e.g. parents applying for childcare allowance, maternity leave, those who care about family members, older workers before old age pension. The employer and employee may enter a contract declaring shortened work time, or extension of shortened working hours to full time. Employees working on shorter work time receive a wage, in accordance with their working hours included in the employment contract. [1]

A mutual trust is required both form the employee and the employer to apply the atypical pattern of employment successfully in the organization. This level of trust, as a part of company culture, as Finna [2] emphasizes, is one of the pillars of long-term cooperation. The absence of cooperation as a key factor can weaken the performance of company in terms of efficiency, competitiveness and profitability [13].

Being familiar with the long-term economic benefits, that is to say, the shift from old tendencies happens, because it can maintain the competitiveness of the company or help to become competitive [10]. The labour market trends show, that employees and employers are ready for mobility and flexibility. Flexibility is considered to be long-term, which requires employees with special characteristics. 
Table 1. The advantages and disadvantages of atypical employment according of the opinion of employer [3].

\begin{tabular}{ll}
\hline $\begin{array}{l}\text { The advantage of atypical } \\
\text { employment }\end{array}$ & $\begin{array}{l}\text { The disadvantage of atypical } \\
\text { employment }\end{array}$ \\
\hline efficient labor utilization & the weakening of direct management \\
& $\begin{array}{l}\text { control } \\
\text { the weakening of the team spirit }\end{array}$ \\
less freedom (holiday) and sickness & $\begin{array}{l}\text { increased training costs } \\
\text { greater competitiveness }\end{array}$ \\
maximizing labor and skills & cost chance of internal communication \\
\hline
\end{tabular}

The research conducted by Frey [3] emphasizes the disappearance of regular and rigid forms of employment patterns, which are gradually replaced by atypical, irregular and flexible patterns of employment. It is important to mention, that this transformation is not a result of external constraints, but the managers of companies apply atypical forms of employment to maintain competitiveness of their businesses. They have recognized and accepted the importance of this change, which can provide help in hiring employees, decreasing unemployment or managing the fluctuation in customer demand.

\section{Research objectives and methodology}

The main objective of the research is to map the employment patterns applied in small and medium-sized enterprises of Nitra region, with a special emphasis to introduce, in what measure businesses apply typical and atypical patterns of employment in a rapidly changing economic environment of the $21^{\text {st. }}$ century.

In order to achieve our research objective we decided to collect primary data with the help of questionnaire survey. We have created a database of small and mediumsized businesses operating in Nitra region. The questionnaire was sent via mail to companies. 320 completed questionnaires were returned and used to examine the issue. The primary data collection was implemented in the first quarter of 2017.

The questionnaire contained 21 questions, which can be categorized as the following:

- questions that focus on fundamental characteristics of research sample;

- the presence of different employment patterns in companies and the information about them;

- flexible employment and related beliefs;

- future plans for employment.

To analyse our research data we used basic descriptive statistical methods, crosstabulation analysis and distribution. 


\section{$4 \quad$ Research results}

$38.84 \%$ of the questionnaires aimed collecting primary data were completed in Komárno district. Relatively high ratio of questionnaires was completed in districts of Nové Zámky (24.79) and Šala (11.57\%). However, our main objective was to examine the employment patterns of small and medium-sized enterprises, we were also interested in the length of operation of business on the market. Closed questions were used to help our respondents to mark, how many years the company has been operating on the market, while adapting to the constantly changing customer needs, as well as meeting the social and legal challenges. A relative majority of companies in Nitra region has been operating on the market for 2-4 years (37.19\%). However, it is also important to point out, that majority of the business involved in the survey have been operating on the market less than 10 years (79.34\%). It means that we get insight into the employment patterns and policy of businesses, which adapt to rapidly changing market needs.

Table 2. The distribution of the examined sample in the districts, operating time

\begin{tabular}{lllllll}
\hline \multicolumn{1}{c}{ District } & $\mathbf{1}$ year & $\begin{array}{l}\mathbf{2 - 4} \\
\text { years }\end{array}$ & $\begin{array}{l}\mathbf{5 - 7} \\
\text { years }\end{array}$ & $\begin{array}{l}\mathbf{8 - 9} \\
\text { years }\end{array}$ & $\begin{array}{l}\text { 10 or more } \\
\text { years }\end{array}$ & Total \\
\hline Komárno & $0.00 \%$ & $10.74 \%$ & $9.09 \%$ & $9.09 \%$ & $9.92 \%$ & $\mathbf{3 8 . 8 4 \%}$ \\
Nové Zámky & $1.65 \%$ & $10.74 \%$ & $7.44 \%$ & $4.13 \%$ & $0.83 \%$ & $\mathbf{2 4 . 7 9 \%}$ \\
Šal'a & $1.65 \%$ & $3.31 \%$ & $3.31 \%$ & $0.00 \%$ & $3.31 \%$ & $\mathbf{1 1 . 5 7 \%}$ \\
Nitra & $0.00 \%$ & $4.96 \%$ & $0.00 \%$ & $0.00 \%$ & $0.83 \%$ & $\mathbf{5 . 7 9 \%}$ \\
Levice & $0.00 \%$ & $1.65 \%$ & $2.48 \%$ & $0.83 \%$ & $2.48 \%$ & $\mathbf{7 . 4 4 \%}$ \\
Zlaté Moravce & $0.00 \%$ & $3.31 \%$ & $0.83 \%$ & $0.83 \%$ & $0.00 \%$ & $\mathbf{4 . 9 6 \%}$ \\
Topolčany & $0.00 \%$ & $2.48 \%$ & $0.83 \%$ & $0.00 \%$ & $3.31 \%$ & $\mathbf{6 . 6 1 \%}$ \\
$\quad$ Total & $\mathbf{3 . 3 1 \%}$ & $\mathbf{3 7 . 1 9 \%}$ & $\mathbf{2 3 . 9 7 \%}$ & $\mathbf{1 4 . 8 8 \%}$ & $\mathbf{2 0 . 6 6 \%}$ & $\mathbf{1 0 0 . 0 0 \%}$ \\
\hline
\end{tabular}

All the companies, providing data for this survey apply the pattern of nine-to-five job. Nearly half of the respondents marked the flexible work pattern as an atypical form of employment. Part-time employment is characteristic for $30 \%$ of the companies, while teleworking sound popular by $2 \%$.

The absolute majority (50.41\%) of businesses involved in our survey provide their business activities in the service sector. Significant rate can be observed in the agricultural sector $(17.36 \%)$, and trade (14.88\%). Although atypical employment pattern can be recognized in all the sectors studied, it is not a widespread phenomena yet. 


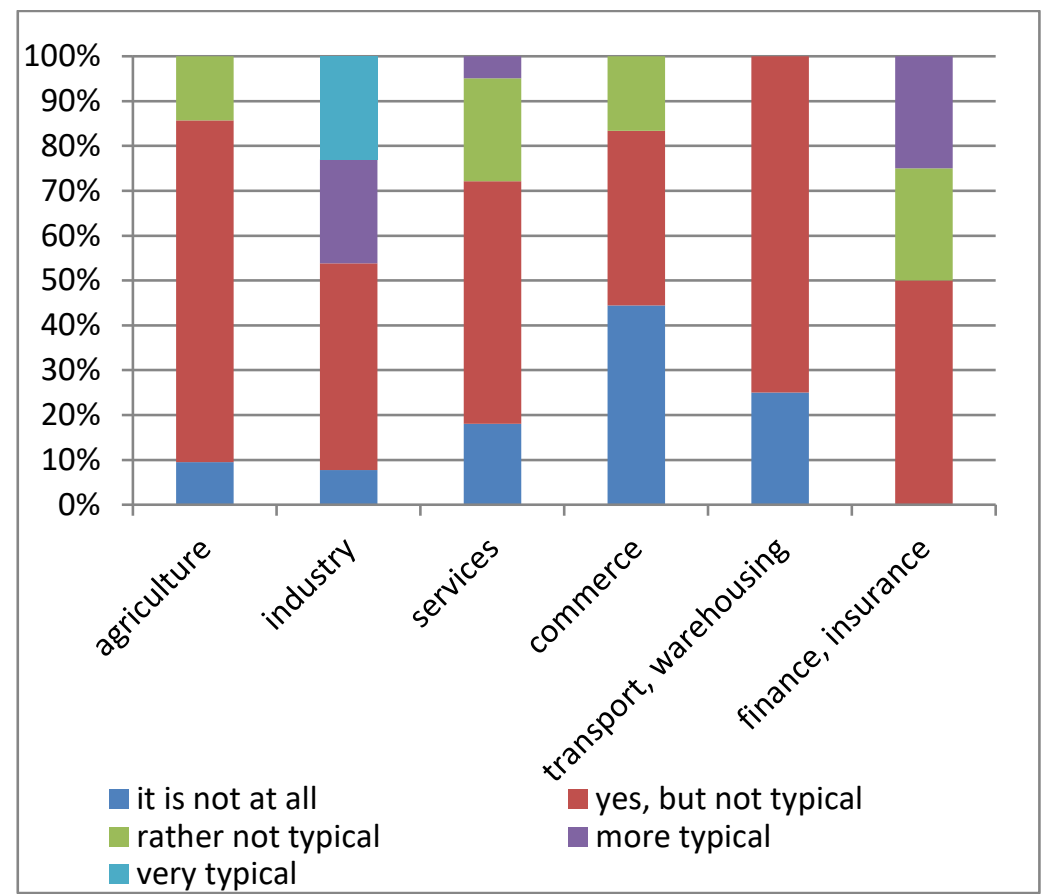

Fig. 1. Industry breakdown of atypical employment

While $23.08 \%$ of the companies in industry sector declared, that atypical pattern of employment is characteristic, other sectors involved in our research show little presence of atypical forms of employment.

By examining the complete sample it can be declared, that atypical patterns of employment can be found in $55.83 \%$ of companies, but it is not characteristic at all. The answers provided by respondents were evaluated on a 5-point Likert scale (1-not typical at all, 5- very typical). The median of responses is 2 and the IQR $=0,5$, which allows us to accept the median as an average response by small and medium-sized enterprises.

Assumption: Atypical patterns of employment are linked to seasonality; therefore, it is a favourite form of employment by companies in agriculture or service sector.

Each of the indicators (Phi, Cramer V, contingency coefficient) show significant value at 5\% significance level. A significant correlation can be shown between the sector the business operates in and how much the atypical pattern of employment is characterisitc for the company. 
Table 3. Phi, Cramer V and contingency coefficient of the econimic sector and the use of atyical forms of employment.

\begin{tabular}{llllll}
\hline & & Value & $\begin{array}{r}\text { Asymp. } \\
\text { Std. Error }^{\mathbf{a}}\end{array}$ & $\begin{array}{l}\text { Approx. } \\
\mathbf{T}^{\mathbf{b}}\end{array}$ & $\begin{array}{l}\text { Approx. } \\
\text { Sig. }\end{array}$ \\
\hline Nominal by & Phi & .683 & & & .000 \\
Nominal & Cramer's V & .342 & & & .000 \\
& $\begin{array}{c}\text { Contingency } \\
\text { Coefficient }\end{array}$ & .564 & & & .000 \\
\multicolumn{1}{l}{$\begin{array}{c}\text { Interval by } \\
\text { Interval }\end{array}$} & Pearson's R & -.130 & .041 & -2.332 & $.020^{\mathrm{c}}$ \\
$\begin{array}{l}\text { Ordinal by } \\
\text { Ordinal }\end{array}$ & $\begin{array}{c}\text { Spearman } \\
\text { Correlation }\end{array}$ & -.153 & .051 & -2.760 & $.006^{\mathrm{c}}$ \\
$\quad \mathrm{N}$ of Valid Cases & 320 & & & \\
\hline
\end{tabular}

a. Not assuming the null hypothesis.

b. Using the asymptotic standard error assuming the null hypothesis.

c. Based on normal approximation.

Applying cross tabulation we examined, which are those economic sectors, where atypical patterns of employment are applied, and which were the most characteristic forms of employment. 50.94\% of the businesses involved in our research represent the service sector. The majority of companies in this group (28.4\% of the total) declared presence of atypical employment patterns in the company, but it is not absolutely characteristic, because traditional patterns of employment are still popular to conduct some temporary tasks.

Table 4. Cross table for the appearance of the economic sector and atypical forms of employment within the companies surveyed.

\begin{tabular}{llllllll}
\hline & \multicolumn{7}{c}{ Yes, } \\
but & $\begin{array}{l}\text { Rather } \\
\text { It is not } \\
\text { at all }\end{array}$ & $\begin{array}{l}\text { not } \\
\text { typical }\end{array}$ & $\begin{array}{l}\text { not } \\
\text { typical }\end{array}$ & $\begin{array}{l}\text { Rather } \\
\text { typical }\end{array}$ & $\begin{array}{l}\text { Very } \\
\text { typical }\end{array}$ & Total \\
\hline Agriculture & $1,88 \%$ & $14,38 \%$ & $2,19 \%$ & $0,00 \%$ & $0,00 \%$ & $18,44 \%$ \\
Industry & $0,63 \%$ & $3,75 \%$ & $0,00 \%$ & $1,88 \%$ & $2,50 \%$ & $8,75 \%$ \\
Services & $9,06 \%$ & $28,44 \%$ & $11,56 \%$ & $1,88 \%$ & $0,00 \%$ & $50,94 \%$ \\
Commerce & $6,25 \%$ & $6,56 \%$ & $2,81 \%$ & $0,00 \%$ & $0,00 \%$ & $15,63 \%$ \\
Transport, warehousing & $0,94 \%$ & $2,81 \%$ & $0,00 \%$ & $0,00 \%$ & $0,00 \%$ & $3,75 \%$ \\
Finance, insurance & $0,00 \%$ & $1,88 \%$ & $0,63 \%$ & $0,00 \%$ & $0,00 \%$ & $2,50 \%$ \\
Total & & & & & & $100,00 \%$ \\
\hline
\end{tabular}

$18,44 \%$ of the researched companies represent the agricultural sector and fisheries. The overwhelming majority of companies in the sector $(77.97 \%$, which is $14.38 \%$ of 
the total sample) have a presence of atypical employment patterns, but those are not clearly characteristic. In this sector, the increase of atypical forms of employment is strongly determined by the seasonality, mainly because of cultivation, crop production, harvesting and foraging. Based on the answer of the respondents, atypical forms of employment are also present, but not clearly characteristic.

On the basis of statistical analysis conducted we can conclude, that Assumption is not completely valid, since atypical employment forms are applied not only in companies of agricultural sector, but other sectors of the economy as well. This is a positive factor, as it helps to make atypical employment patterns widespread, and can help the active population to make their work-life balance better.

Based on the analysis of data obtained, we managed to set up a chronological order of those atypical patterns of employment companies prefer.

Table 5. Preferred atypical forms of employment.

\begin{tabular}{ll}
\hline Sequence & Atypical forms of employment \\
\hline $\mathbf{1}$ & Flexitime \\
$\mathbf{2}$ & Part-time employment \\
$\mathbf{3}$ & Seasonal / casual work \\
$\mathbf{4}$ & Employment with the fix-term employment contract \\
$\mathbf{5}$ & Work on telework / variable locations, hire of staff \\
$\mathbf{6}$ & Home work (incorporation) \\
\hline
\end{tabular}

Flexitime was the most popular atypical form of employment, which treats the required number of working hours in a month or week flexibly. Part-time employment was marked as the second, which means reduced hours of employment compared to full-time contractors. If the workload does not require a full-time employee, this pattern of atypical employment can be an ideal choice for cost-efficiency. Seasonal /casual work was third in a rank. As the research sample was mainly represented by companies of agricultural and service sector, it is not surprising, that seasonal work is mainly characteristic in the mentioned sectors and has gained a prestigious position.

By analysing the responds of the questionnaire survey we can assume, that $75 \%$ of the respondents have inadequate information about the atypical patterns of employment. It is positive that $44.17 \%$ of the companies show willingness to participate occasionally on trainings about atypical patterns of employment. The companies have already recognized the changing legal, market and social conditions, and they would like to respond to them. By employing atypical forms of employment, the consumer demand can be fulfilled at a higher level, also can change the employment of economically active population, and they can choose the most effective employment policy for themselves.

The organizational structure of companies requires the creation of different working positions within a company. After studying the scientific literature, the staff members who work in different positions can be classified as the following: employees performing operative tasks, employees at lower managerial levels, middle 
and senior management level. The grouping was necessary to examine which group is more likely to use atypical patterns of employment. According to the respondents, atypical forms of employment are less likely to be used by lower managerial levels (23\%). Nearly one-third of the employees performing operative tasks work in different than a nine-to-five job, while atypical forms of employment are the most frequent among middle and senior management positions (43\%). If the company uses atypical patterns of employment in case of operative tasks, the work is usually outsourced to students (24\%) or pensioners (13\%).

Our research sample clearly shows that better work-life balance is the biggest benefit of applying atypical patterns of employment. This fact can confirm our previous statement: the companies of the $21^{\text {st. }}$ century put emphasis on the changing societal and social environment, and also consider the needs of their employees, since high quality private life is as important as their work.

Table 6. The advantage of atypical employment for the company.

\begin{tabular}{cl}
\hline Sequence & The advantage of atypical employment for the company \\
\hline $\mathbf{1 .}$ & Better coordination between work and private life \\
$\mathbf{2}$. & More efficient labor exploitation \\
$\mathbf{3 .}$ & Better job utilization in line with production requirements \\
$\mathbf{4 .}$ & Cost savings \\
$\mathbf{5 .}$ & Increase competitiveness \\
\hline
\end{tabular}

The further analysis of our primary research data revealed, that part-time job is the most frequently chosen form of atypical employment patterns, which means that an average employee employed part-time works 20-30 hours during a working week $(78 \%)$

Regarding the size of the companies, atypical employment patterns are mainly used by micro businesses, especially part-time employment seems to be popular. The fact is not surprising, since it is the group of companies that employ fewer people, often on a seasonal basis or to avoid layoffs. Surprising is the fact, that the most widespread employment pattern different from traditional nine-to-five working hours was the part-time job. It is important to emphasize, that in many cases the respondents were not familiar with the characteristic features, benefits, disadvantages and legal background of the employment pattern.

\section{Conclusion}

In the rapidly changing socio-economic environment of the $21^{\text {st. century, due to }}$ constantly changing market and consumer demands we should emphasize the expansion of atypical patterns of employment as a different phenomenon from the standard nine-to-five employment form. The companies have already recognized this fact, but there is still low number of companies introducing atypical patterns of 
employment (part-time employment is popular). It is necessary to address this issue as soon as possible. The suggestion can be summarized as the following:

- Active support by the Labour Office - the Labour Office has already provided various forms of support to companies and start-ups. The programmes, primarily designed to start businesses are proposed to be supplemented by programmes to inform entrepreneurs about the atypical patterns of employment and the benefits of these new forms of employment, since the start ups should pay attention on the rapidly changing needs of their potential customers to satisfy their increasing standards, as well as pay attention on the cost-effective employment policy.

- Active support provided by local, regional and other economic organizations there has been an increase in various organizations, companies and groups aimed at reviving the economic and entrepreneurial life. Their business events, conferences, forums should serve a task to provide information and emphasize the advantages of atypical forms of employment on the labour market.

\section{References}

1. Bak-Grabowska, D., Jagoda, A.: Non-standard forms of employment and working time flexibility - The categories of co-occurance? Journal of International Studies 9(1), 229239 (2016), DOI: 10.14254/2071-8330.2016/9-1/17.

2. Finna, H.: A funkcionális munkaerőpiaci rugalmasság alkalmazásának nemzetközi tapasztalatai. Pannon Egyetem, Veszprém (2007).

3. Frey, M.: A munkaidőrendszerek rugalmassá válása. Közgazdasági Szemle 47, 1008-1026 (2000).

4. Frey, M.: Aktív munkaerőpiaci eszközök működésének értékelése 2001-2006 között és változásai 2007-ben. Munkaeröpiaci tükör 2007. MTA, Budapest (2007).

5. Hanzelová, E., Kostolná, Z., Reichová, D.: Atypické formy zamestnanosti na Slovensku: minulost' a súčasnost'. Rodina a práca 2005(3), 1-31 (2005).

6. Hárs, Á.: Az atipikus foglalkoztatási formák jellemzői és trendjei a kilencvenes és a kétezres években. TÁMOP - 2.3.2-09/1, Mühelytanulmány T/13, (2012).

7. Kazuya, O.: International Comparison of Atypical Employment: Differing Concepts and Realities in Industrialized Countries. Japan Labor Review 2(2), 5-29 (2005).

8. Kiral'ová, A., Malec, L.: Communication and Managerial Competences as a Prerequisite for Employability of Graduates in Tourism. In: Soliman, K. S. (eds.) Crafting Global Competitive Economies: 2020 Vision Strategic Planning \& Smart Implementation, IBIMA conference 2017, vol. 24, pp. 477-488. IBIMA, Italy (2017).

9. Kirillová, L. S., Lushnikov, A. M., Vladimirovna, L. M.: Atypical Employment Contracts: Between Flexibility of the Labor Market and the Protection of Workers' Rights. Turkish Journal of Design Art and Communication. 6, 2904-2909 (2016), DOI: 10.7456/1060NVSE/101.

10. Laczkó, Zs.: Mi minden segíti, ill. gátolja az atipikus foglalkoztatások elterjesztését? Konferenciaelőadás, A foglalkoztatásbővítés atipikus lehetőségei uniós tapasztalatainak közreadása a hazai foglalkoztatási célú civil szervezetek számára. Szociális Innováció Alapítvány, Budapest (2007). 
11. Makó, Cs., Simonyi, Á.: Szervezeti rugalmasság - Új termelésszervezési megoldások. In: Kőváry Gy. (eds.) A felzárkózás esélyei, pp. 96-116. MTA: Közgazdaságtudományi Intézet, Budapest (2003).

12. Mendez, L. M.: New Forms of Employment is Spain after the 2012 Reform: The „Working Time“ Factor as a Tool to make „Distance Work“ more Flexible. E-Journal of International and Comparative Labour Studies 5(3), 274-292 (2016).

13. Orlova, N. A.: Non-standard forms of employment and changes in human capital: Analysis of the unskilled labor migration to Russia. Monitoring Obshchestvennogo Mneniya: Ekonomichekie i Sotsial'nye Peremeny 137(1), 156-170 (2017), DOI: 10.14515/monitoring.2017.1.10.

14. Slovak Business Agency: Malé a stredné podnikanie v číslach v roku 2015, http://www.sbagency.sk/sites/default/files/msp_v_cislach_v_roku_2015_0.pdf, last accessed 2017/05/26

15. Takácsné György, K., Benedek, A.: Bizalmon alapuló együttműködés vizsgálata a kis- és középvállalatok körében. In: Csiszárik-Kocsir, Á. (eds.). Vállalkozásfejlesztés a XXI. században, pp. 379-390. Óbudai Egyetem. Keleti Károly Gazdasági Kar, Budapest (2016). 